ROCZNIKI TEOLOGICZNE

Tom LXVI, zeszyt 5 - 2019

DOI: http://dx.doi.org/10.18290/rt.2019.66.5-6

ANDRZEJ JASTRZĘBSKI OMI

\title{
CONCEPTS OF SPIRITUALITY AT UNIVERSITIES OF TODAY
}

\begin{abstract}
In today's world, the concept of spirituality has entered into an extremely dynamic phase. This evolution is especially noticeable in the way spirituality is being taught at various universities. This paper will discuss studying spirituality from a Roman Catholic perspective viewed in a combination of four dimensions: ontological or phenomenological and foundational or pragmatic. It will take into account future directions in the approach to spirituality, including the ecumenical (Christian), the interreligious, and the non-religious.

The aim of this paper is to develop the above-stated characteristics based on some chosen examples of university curricula, then having done so, to elaborate a comparative analysis of the understanding of spirituality and its implications for academic programs.
\end{abstract}

Key words: spirituality; theology; university.

In today's world, the concept of spirituality has entered into a dynamic phase. This evolution is especially noticeable in the way spirituality is being taught at various universities. Generally speaking, the approach to studying spirituality can be divided into a combination of four factors or dimensions: ontological or phenomenological and foundational or pragmatic. It may be viewed "from above" when linked to dogmatic theology and the notion of grace or "from below" when connected to the social sciences of anthropology, sociology and most often psychology, studying spirituality in simple everyday human life. We will go into more details on this topic later in the text.

The first distinction refers to the metaphysical foundation of studying spirituality. In the ontological (or substantive) approach, the question of the existence of God or, more broadly, that of the Sacred, will be addressed. ${ }^{1}$

Dr hab. ANDRZEJ JASTRZĘBSKI OMI, prof. USP School of Counselling, Psychotherapy \& Spirituality, Faculty of Human Sciences, Saint Paul University; address: 223 Main Street, K1S 1C4, Ottawa, ON Canada; e-mail: ajastrzebski@ustpaul.ca

${ }^{1}$ Por. D. OMAN, "Defining religion and spirituality," in Handbook of the psychology of religion and spirituality, ed. R.F. PAloutZian, C.L. PARK (New York: The Guilford Press, 2013), 35. 
This is the traditional approach to the understanding of spirituality as found in St. Paul's writings, where he opposes spirituality to human carnal tendencies and relates it to a life profoundly marked by the presence of the Holy Spirit as spiritual fruits as peace, joy, or charity become apparent.

The phenomenological (or functional) approach, by defining what purpose spirituality serves, is mainly interested in the spiritual state or spiritual experience. ${ }^{2}$ Its impact on the individual's life is considered, but the transcendent component of the relationship is disregarded. In such an approach to spirituality, a direct description of the subject is more valued than any objective theological argumentation.

The foundational approach to the understanding of spirituality's aim is to define spirituality in such a way that it can be assessed thereafter as being sound or not. In this approach, spiritual practices are viewed in their religious or philosophical perspective as an integral part of the larger system; whereas in the pragmatic approach spiritual practices are viewed independently and separately from their spiritual source or larger frame.

Furthermore, spirituality is addressed both specifically within the Christian Tradition according to different schools of spirituality (Ignatian, Carmelite, and others) and through topics such as spiritual discernment or methodology of spirituality.

The aim of this paper is to illustrate the above sketched particularities, and based on various examples of university curricula, elaborate a comparative analysis of the understanding of spirituality and its implications for academic programs.

\section{DIVERSITY OF CONCEPTS}

In the history of philosophy and theology, the concept of spirituality had been primarily understood and defined as immateriality; the concept of immortality only became more prevalent in more recent years. For many Greek philosophers, the spiritual and the material were mutually exclusive and they considered immateriality to be the fundamental trait of the human spirit. ${ }^{3}$ Spirituality in this philosophical sense entailed separateness from matter, i.e. immateriality and pointed to the spiritual element in the human being. In the

\footnotetext{
2 Ibidem.

${ }^{3}$ T. ŠPidlik, I. Gargano, V. Grossi, "Duchowość Ojców Kościoła," in Historia duchowości, vol. 3 (Kraków: Homo Dei, 2004), 10.
} 
classic Aristotelian sense, immateriality became a "form," a permanent nature. ${ }^{4}$ It was not until the sixteenth century, called the golden age of mysticism, that spirituality began to refer to the inner life, and, specifically, to prayer. $^{5}$

Today, although they continue to do so, defining spirituality is no longer reserved to theologians. Mental health practitioners, philosophers, sociologists and psychologists each propose their own point of view on spirituality. We will illustrate this below by some chosen examples.

\subsection{Traditional approach}

The longstanding traditional understanding of spirituality defines it as a form of religious life leading to union with God the Father through Jesus Christ in the Holy Spirit. More specifically, the Christian understanding of spirituality covers popular piety, religious asceticism, mysticism, but also morality (ethos). In a more traditional context, spirituality means living a life in which one accepts the sacred as something of ultimate value and progressively shapes one's own existence in the pursuit of one's spiritual growth. ${ }^{6}$

Saint Paul, in his first letter to the Corinthians states that "this is what we speak, not in words taught us by human wisdom but in words taught by the Spirit, interpreting spiritual truths to those who are spiritual" (1 Cor 2:13). Spirituality is thus an opening to the Holy Spirit. "Those who are spiritual" differ from others, because they act under the influence of the Holy Spirit. ${ }^{8}$ Józef Tischner, an eminent Polish priest and philosopher, states that spiritual life is focused on serving God, the giver of goodness and that this allows us to pass from despair to hope. ${ }^{9}$ Henri Bergson proposes to view human spirituality in reference to the lives of the Christian mystics. ${ }^{10}$ Finally, von

${ }^{4}$ R. DAROwSKi, Filozofia czlowieka, Zarys problematyki (Kraków: WAM, 2002), 66-67.

${ }^{5}$ S.M. SCHNEIDERS, "Spirituality in the Academy," Theological Studies (1989), 50: 681.

${ }^{6}$ M. DANILUK, "Duchowość chrześcijańska," in Encyklopedia Katolicka, vol. 4 (Lublin: TN KUL, 1985), 317-330; S. WiTEK, "Duchowość religijna," in Encyklopedia Katolicka, vol. 4, 330-334; M. ChMielewski, "Duchowość," in Leksykon duchowości katolickiej, ed. M. Chmielewski (Lublin-Kraków: Wydawnictwo M, 2002), 226-232.

${ }^{7}$ J.O. Wiseman, Spirituality and Mysticism: A Global View. Theology in Global Perspective Series (Maryknoll, NY: Orbis Books, 2006), 2.

${ }^{8}$ S.M. SCHNEIDERS, "Spirituality in the Academy", 681.

${ }^{9}$ J. Tischner, Spór o istnienie czlowieka (Kraków: Znak, 1998), 287.

${ }^{10}$ K.A. WoJCIESZEK, Na początku była rozpacz... Antropologiczne podstawy profilaktyki (Kraków: Rubikon,2005), 94. 
Balthasar affirms that spirituality is "That basic practical or existential attitude of man which is the consequence and expression of the way in which he understands his religious-or more generally, his ethically committed-existence." 11

Even from the non-theological context, there are voices suggesting that spirituality has to be defined in relationship with religion because the word spirituality has historically been associated with religion and Transcendence. Under this concept, defining spirituality would always have to be done within the parameters of religion. ${ }^{12}$

\subsection{New approach}

Today spirituality has taken on a variety of new meanings. Spirituality may be viewed as an integral part in defining personal identity and the individual experience of the sacred. ${ }^{13}$ Spiritual phenomena can be defined in many different ways:

- as a fundamental dimension of our existence, as a specific sort of experience; ${ }^{14}$

- as reaching a deeper union with the universe;

- as searching for a higher meaning of life;

- as acquiring a balanced and tolerant attitude towards life;

- as developing such characteristics of being as humility, joy, and compassion;

- as being a humble and loving self;

- as reaching the essence of existence.

Those are only a few examples.

The contemporary understanding of spirituality encompasses a very diverse range of personal phenomena. It is related to prayer and similar practices but is not confined to the Christian tradition. It may pertain, for example, to the 'inner life' of someone who through prayer and ascetic practices is trying to achieve greater excellence. Furthermore, spirituality also de-

${ }^{11}$ H.U. von Balthasar, "The Gospel as Norm and Test of All Spirituality in the Church," Concilium (1965), 9: 7.

${ }^{12}$ H.G. Koenig, Medicine, Religion and Health: Where Science and Spirituality Meet (West Conshohocken: Templeton Press, 2008), 17.

${ }^{13}$ T. Gall, J. Malette, M. Guirguis-Younger, "Spirituality and Religiousness: A Diversity of Definitions," Journal of Spirituality in Mental Health (2011), 13/3: 158-181.

${ }^{14}$ M. SCHNEIDERS, "Spirituality in the Academy," 678. 
scribes the entire experience of faith, or even the fullness of one's personal life, along with its manifold dimensions: somatic, psychic, and socio-political. ${ }^{15}$ One may add that normally spirituality would always be accompanied by an appropriate praxis. ${ }^{16}$

Nowadays, in contemporary philosophy, we are dealing with very different notions of spirituality. For example, Richard Rorty describes spirituality pragmatically, reducing it to a matter of one's personal preference ${ }^{17}$ Charles Taylor proposes to recognize spirituality as a discourse of wisdom, referring to the moral dimension of life. ${ }^{18}$

Another contemporary example of the new understanding of spirituality is given to us by Daniel Helminiak. He defines spirituality broadly as the thoughtful engagement of a human person within the process of full growth in humanity. ${ }^{19}$ Likewise, David Elkins points out to the following dimensions of spirituality: the desire for something transcendent; the desire to relate our existence to something beyond; the desire for an object that is a separate and higher reality. ${ }^{20}$

\subsection{Integration of approaches}

In conclusion to this part we can state that spirituality can be viewed from either a bottom-up or top-down perspective. ${ }^{21}$ The first is a functional approach (that of sociology, psychology, etc.), which shows the role of spirituality within the dynamism of being human (phenomenology). On this ground, one can argue that virtually all human life has a spiritual dimension. Another possibility is a substantive approach located within the Christian tradition. It attempts to define spirituality in the light of sanctifying grace descending on the human person from God and as a result, demonstrates

\footnotetext{
${ }^{15}$ Ibidem, 79.

${ }^{16}$ J.B. RuBin, "Psychoanalysis and spirituality," in Psychoanalysis and religion in the 21 st century: Competitors or collaborators, ed. D.M. Black (New York: Routledge, 2006), 132-153.

${ }^{17}$ Z. ZABORowski, Człowiek jego świat i życie. Próba integracji (Warszawa: Wydawnictwo Akademickie „Żak”, 2002), 382.

${ }^{18} \mathrm{Ch}$. TAYLOR, Sources of the Self. The Making of the Modern Identity (Cambridge, MA: Harvard UP, 1989), 35, 50.

${ }^{19}$ D.A. HelminiaK, "Confounding the Divine and the Spiritual: Challenges to a Psychology of Spirituality," Pastoral Psychology (2008), 57: 162.

${ }^{20}$ D.N. ELKINS, Beyond religion: A personal program for building a spiritual life outside the walls of traditional religion (Wheaton, IL: Quest Books, 1998), 31.

${ }^{21}$ M. SCHNEIDERS, "Spirituality in the Academy," 682.
} 
spirituality's place in the structure of the human being (ontology). Elsewhere, some authors (e.g. Oman, Koenig, Puchalski ${ }^{22}$ ) propose to use mixed, substantial-functional definitions of spirituality.

The spiritual nature of the human person can be also seen in human rationality, and more specifically, in one's mental faculties: the intellect and will. Some thinkers emphasize the intellect, others the will. ${ }^{23}$ Nowadays, more emphasis has been placed on consciousness. The modern debate around the nature of consciousness opens up a new perspective to a broad definition of spirituality.

One could continue studying different concepts of spirituality, but now we shall relate this discussion to the specific academic locations.

\section{THE INSTITUTE OF SPIRITUALITY AT THE PONTIFICAL GREGORIAN UNIVERSITY IN ROME}

The Institute of Spirituality is connected to the Faculty of Theology of the Pontifical Gregorian University. Its intent is to be a center of reflection and teaching of Spiritual Theology in dialogue with other theological disciplines, and also, in a broader perspective, with the social sciences. A specific characteristic of this approach is also marked by the Ignatian school of spirituality. $^{24}$

The principle purpose of the Institute of Spirituality is to develop a theological and spiritual synthesis emphasizing a sapiential approach in conjunction with the use of spiritual discernment. The Institute also intends to favor an authentic and integral formation of its students by means of training in Ignatian spirituality. The desired fruit of this process is an integral and multidimensional maturation of the participant: intellectual, human and spiritual. ${ }^{25}$

Following the ontological and foundational approach to spirituality in a specific Ignatian context, the objective of the Institute of Spirituality is to help the students to become authentic witnesses of the Gospel. This for-

${ }^{22}$ C. PUCHALSKI ET AL., "Improving the quality of spiritual care as a dimension of palliative care: the report of the Consensus Conference," Journal of Palliative Medicine (2009), 12(10): 887: "The way individuals seek and express meaning and purpose and the way they experience their connectedness to the moment, to self, to others, to nature, and to the significant or sacred."

${ }^{23}$ W. Granat, Osoba ludzka. Próba definicji (Lublin: TN KUL, 2006), 280.

${ }^{24}$ www.unigre.it/struttura_didattica/Spiritualita/index_en.php (01.12.2018).

${ }^{25}$ Ibidem. 
mation should also help the students to become efficient interlocutors in a dialogue with the contemporary world and other spiritual traditions. ${ }^{26}$

The courses offered at the Institute are visibly impregnated by the Ignatian school of spirituality with both historic courses and specific additions, for instance, in the seminar on "The Holy Spirit in the Gospel of John." The main body of courses are a detailed presentation of the Ignatian spiritual tradition: Ignatius and woman; Ignatius of Loyola; Person, mystic, spirituality; Ignatian sources; The Society of Jesus, 1814-2014; Discernment of spirits in the life of St. Ignatius of Loyola; Spiritual Exercises: structure and underlying theology; The Ignatian spirituality; The Ignatian mystical tradition; History of the Society of Jesus from its origin to the present; Ignatius of Loyola, his youth and conversion, The psychology of the Spiritual Exercises. ${ }^{27}$

The Institute of Spirituality at the Pontifical Gregorian University in Rome presents a traditional approach to understanding spirituality in light of its in-depth teaching of the Ignatian tradition. Certainly it is an ontological approach where the existence of God is accepted and the relationship with God plays the central role within defining spirituality. Hence, it is also foundational. There is also the phenomenological dimension present, especially in describing the way of St. Ignace.

\section{THE THEOLOGICAL FACULTY OF SAINTS TERESA OF JESUS AND JOHN OF THE CROSS - PONTIFICAL INSTITUTE OF SPIRITUALITY}

This Institute presents the whole history of Christian spirituality with an emphasis on the Carmelite Tradition as seen in the academic curriculum. Here are some examples of courses:

Saint Teresa of Jesus: fundamental themes of spirituality; To believe, to hope, to love, according to St. John of the Cross; The theology of Saint Teresa of Lisieux, Doctor of the Church; The contribution of St. Teresa of Jesus to theological anthropology; St. Elizabeth of the Trinity: a prophetic paradigm for the people of today; Keys for the reading of St John of the Cross; Edith Stein's spirituality as the unfolding of her anthropology; The process of transformation of the spiritual man in Saint John of the Cross. ${ }^{28}$

\footnotetext{
${ }^{26}$ Ibidem.

${ }^{27}$ www.unigre.it/zz2_applicazioni/framework_en.php?adg_utente=unknown\&adg_pgm=204\&ad g_ua $=7(21.11 .2018)$.

${ }^{28}$ www.teresianum.net/specializzazione-in-teologia-spirituale/ciclo-per-la-licenza-ts/ (22.11.2018).
} 
Currently, the Institute of Spirituality is structured in four sections:

- an academic section of specialization, with two cycles: one for the License and one for the Doctorate;

- a section of Spiritual Theology, with its Diploma and two teaching methods: residential and online;

- a section for Formators and Heads of Communities of Consecrated Life and Societies of Apostolic Life, with the corresponding Diploma (postgraduate);

- a section of Spiritual Counseling in the Catholic field, with a corresponding Diploma (post-graduate).

Due to some adjustments to Italian law, a course on Spiritual Accompaniment, scheduled for the academic year 2019-2020, is being prepared to replace the Spiritual Counseling Course. ${ }^{29}$

The Course of Spiritual Counseling in the Catholic environment - School of Mystagogy at the Teresianum presents the fruit of the Carmelite tradition or school of spiritual accompaniment. This, initiated by two mystical Doctors, St. Teresa of Jesus and St. John of the Cross, introduces the theological life of faith, hope and love as the way to mysticism: union with God. Among Carmelite disciples who stand out, we find St. Thérèse of Lisieux, B. Elisabeth of the Trinity, and S. Edith Stein. Through the Course of Spiritual Counseling in Catholic environment - School of Mystagogy, the experience of the Carmelite Mystics and their teaching are transmitted during the process of formation of Counselors. ${ }^{30}$

As a consequence, this course intends to be a school of mystagogy. In the context of Teresianum, the figure of the mystagogue is designated by the term Spiritual Counselor. The word mystagogy finds its root to the term mysterion, with a suffix from the Greek verb agein (guide), thus indicating the concrete meaning of guiding towards or beginning to enter the experience of Mystery. It is therefore a form of pedagogy meant to accompany people, along the path that leads to the experience of Mystery. ${ }^{31}$

Spiritual Counseling requires the Counselor to remain in contact with the discomfort of others, which arises in moments of existential crisis, in the effort of making decisions, in family and community relational difficulties, and in illness and mourning; the Counselor learns to listen to the spiritual

\footnotetext{
${ }^{29}$ www.teresianum.net/facolta/ (26.11.2018).

${ }^{30}$ www.teresianum.net/counseling-spirituale/presentazione/ (05.12.2018).

${ }^{31}$ Ibidem.
} 
dimension of the person, accompanying them in their search for meaning and standing by their side without suggesting any particular solutions. ${ }^{32}$

The Course of Spiritual Counseling in the Catholic environment - School of Mystagogy offers a basic formation on the main topics of Spiritual Theology, based on the teaching of the Carmelite Mystics. At the same time, it offers psychology courses and a number of hours of practicum to ensure a suitable level of training, prerequisites for a future professional level in the exercise of Counseling. ${ }^{33}$ As stated before, starting in the academic year 2019-2020, a Course on Spiritual Accompaniment will be activated. It is intended for priests, consecrated persons and lay people who are involved in the pastoral care of accompaniment, for example as chaplains in schools, universities, or hospitals as well as for persons who have a mission as chaperones in listening centers or youth groups, or those who preach the Spiritual Exercises. ${ }^{34}$

The course will help pastoral agents at different levels, first of all with regards to the theological foundations of spiritual accompaniment, which essentially refer to a deepening understanding of the Word of God as a source of discernment. The training received serves to develop skills related to the guidance of people, proposing criteria for discernment and analysis tools, along with the contribution of the human sciences. The course also offers practical training in spiritual accompaniment. ${ }^{35}$

Teresianum, similary to the Institute of Spirituality at the Pontifical Gregorian University, proposes an ontological and foundational approach to spirituality articulated through its own Carmelite tradition. At Teresianum, a pragmatic or practical aspect is also present.

A new challenge is appearing regarding the formal status of Spiritual Counseling versus national associations of mental health practitioners. In North America, as we will see in the last example, this process led to laicization or "universalization" of pastoral counseling in order to remain accredited by psychological associations. In the case of Teresianum, there is yet a different turn of events. The program of pastoral counselling is becoming more "spiritual" and is shifting into a school of spiritual accompaniment.

\footnotetext{
32 Ibidem.

${ }^{33}$ Ibidem.

${ }^{34}$ www.teresianum.net/counseling-spirituale/presentazione/ (26.11.2018).

${ }^{35}$ Ibidem.
} 


\section{JOHN PAUL II CATHOLIC UNIVERSITY OF LUBLIN (POLAND), FACULTY OF THEOLOGY, INSTITUTE OF SPIRITUAL THEOLOGY}

The Institute offers the possibility of specialized studies in the area of spiritual theology. Here, the accent is put on studying the relationship between God and spiritual experiences as well as attitudes shaped by it. Fundamental issues presented in the program of studies are examined from three basic points of view: Biblical-theological, historical, and psychological. The program is directed to priests, consecrated persons and lay people who desire to deepen their Christian spiritual experience and it prepares a person for work as a lecturer on spiritual theology or as a spiritual director. The program can also be helpful for those who will work as leaders in the area of formation, either in religious orders and communities of consecrated life, or in parish communities. ${ }^{36}$

Students of the Institute of Spiritual Theology, in the framework of twoyears licentiate studies and then doctorate studies, are offered the possibility of taking advantage of a wide selection of discussions around pertinent issues, presented during the lectures, seminars and discussion classes. The topics of lectures on subjects includes, among others: methodology of spiritual theology, anthropological and Biblical basis for spirituality, spiritual development and its principle sources (prayer, meditation, contemplation), the history of Christian spirituality and the Polish Church's spirituality, comparative spirituality, Eucharistic and Marian spirituality, Islamic and Buddhist spirituality, spirituality pertaining to the rule of religious orders, and spiritual direction. ${ }^{37}$

The Institute also offers Post-Graduate Studies of Catholic Spirituality. These studies, according to their nature, prepare graduates to undertake assignments in spiritual accompaniment, in animation of prayer-apostolate groups, and other similar ministries. Among others, students will be familiarized with the following issues: spiritual development, principles of interpersonal communication, women's and men's spirituality, spiritual crisis, satanic bondage, principles of spiritual accompaniment, and resolving conflicts in a community. ${ }^{38}$

The Institute of Spirituality leads a broad range of research on Catholic spirituality related to the Polish context. Some major topics of interest are:

\footnotetext{
${ }^{36}$ www.kul.pl/studies,21677.html (23.112018).

${ }^{37}$ Ibidem.

${ }^{38}$ Ibidem.
} 
methodology of spiritual theology, Biblical and theological bases of spirituality, spirituality of different groups in the Church, the sacramental dimension of spiritual life and the history of Polish spiritual theology. ${ }^{39}$ In the academic work of the Institute, the following issues are given a high priority: methodology of spiritual theology, anthropological bases of spirituality, spiritual development and its principle means, as prayer and contemplation, as well as comparative spirituality. ${ }^{40}$

\section{SAINT PAUL UNIVERSITY IN OTTAWA}

Spirituality at Saint Paul University has been subject to many changes and could to some extent be an example of possible scenarios that may also begin to happen in Europe. The program that in 1974 started as a program of pastoral counseling and was preparing counselors mainly in Christian-Catholic environment has now become the School of Counselling, Psychotherapy and Spirituality. At the BA level, this program is called Human Relations and Spirituality. The core courses in these programs are designed to develop better interpersonal communication as well as a good understanding of psychospiritual development in view of different cultural and spiritual traditions.

The program involves two main disciplines: human sciences and spirituality. The latter is understood as the relationship with a supreme being and with other fellow humans. ${ }^{41}$

This understanding of spirituality is displayed in the names of courses: Human Behavior and Spirituality: Theoretical Foundations; Human Behavior and Spirituality: Empirical Observations; Positive Psychology and Spirituality; Developmental Psychology, Spirituality and Religiosity from Childhood to Adolescence; Developmental Psychology, Spirituality and Religiosity from Adulthood to Old Age; Psychology of Spiritual Experience; Cultural Diversity and Religious Pluralism; Family and Spirituality; and Psychopathology: Causes and Impact on Human Relationships and Spirituality. ${ }^{42}$

At the Masters level, the School of Counselling, Psychotherapy and Spirituality offers programs in Individual Counselling/Psychotherapy and Spiri-

\footnotetext{
${ }^{39}$ www.kul.pl/research,21678.html (05.12.2108).

${ }^{40}$ www.kul.pl/department-of-theology-of-catholic-spirituality,2733.html (05.12.2018).

${ }^{41}$ www.ustpaul.ca/program-new/honours-bachelor-of-arts-in-human-relations-and-spirituality -324.htm (23.11.2018).

42 www.ustpaul.ca/program-new/honours-bachelor-of-arts-in-human-relations-and-spirituality -324.htm (07.12.2018).
} 
tuality, in Couple Counselling and Spirituality and in Spiritual Care for students who want to become hospital or school chaplains.

The objective of this program is to train counselors/psychotherapists who encounter individuals and couples in a therapeutic context, while respecting their values and spirituality. ${ }^{43}$ This means that students are being prepared to understand spirituality very broadly and universally. In all of the practicum in the first and second years students are taught how to integrate spirituality in the therapeutic context in a very practical manner. The practical component of the program refers to the spiritual praxis that we mentioned earlier in the text. The courses offered to equip them for this task are Practical Theology, Counseling and Spirituality, Professional Issues and Ethics in Spiritual Care, Theology of Spiritual Care and Clinical Pastoral Education (CPE) ${ }^{44}$

Beyond this more psychological approach, there is also a program within theology that addresses spirituality: the Contemplative Theology and Spiritual Mentorship graduate diploma. This program's goal is to teach students, from a theological perspective, to understand the nature and dynamics of contemplation, as well as to identify links between human sciences and spiritual traditions, in order to better help foster healthy relationships. ${ }^{45}$ Again, from the theological perspective, spirituality here is conceived very universally or philosophically in relationship to psychology. The courses thought to substantiate this approach are as follows: Self-Understanding: Hermeneutical Theories and Methodological Integration; Issues and Conditions for a Contemplative Renewal; Steps on the Path towards Fullness: Methods and Issues; The Master-Disciple Relationship and Spiritual Mentorship; Contemplative Theology, Psychotherapies and Spiritual Traditions: A Dialogical Approach. ${ }^{46}$

\section{CONCLUSIONS}

There has been a number of changes regarding spirituality in academia. Most probably these changes are inevitable. Two major factors that play an essential role in these transformations and developments lie in the dynamic

${ }^{43}$ www.ustpaul.ca/program-new/counselling-and-spirituality-302.htm (23.11.2018).

${ }^{44}$ www.ustpaul.ca/program-new/counselling-and-spirituality-302.htm (07.12.2018).

${ }^{45}$ www.ustpaul.ca/program-new/contemplative-theology-and-spiritual-mentorship-314.htm (07. 12.2018).

${ }^{46}$ www.ustpaul.ca/program-new/contemplative-theology-and-spiritual-mentorship-314.htm (07. 12.2018). 
interplay or dialog of different spiritual traditions and the relationship of spirituality with science - especially with social sciences such as psychology and sociology.

We can observe that spirituality has become more phenomenological, i.e. descriptive, rather than dogmatic as well as pragmatic, i.e. parallel and equivalent to any other dimensions of human life. Some would go even further and become eclectic regarding spiritual practices (like meditation and mindfulness) without linking them to any spiritual system or school. Spirituality can be treated as any accessible means of improving human life's conditions.

Even if one accepts the phenomenological approach to studying spirituality, there remain certain relevant questions to be answered: Is spirituality "countable" or "uncountable"? Can one make spirituality a purely quantitative aspect of human life and apply only statistical methods to measure it? Or should one always take into account the qualitative side of this phenomenon? Should one go more towards an idiographic way of researching spirituality (case studies) or is one allowed to apply a nomothetic approach? ${ }^{47}$

One of the key factors that define spirituality today is the relationship between religion and psychology. ${ }^{48}$ At Teresianum, there is a movement from counseling to spiritual accompaniment, i.e. from psychology to a more religious viewpoint. At Saint Paul University, there is the reverse tendency. Generally speaking, it seems that the notion of spirituality will tend to develop in a more universal direction as required by the new characteristics of our students. One of the possible directions is that spirituality taught at the Catholic Institutes will become more ecumenical (Christian), then interreligious, as we witness a significant interest around Buddhism, and finally come to include even the non-religious, thus embracing all possible human spiritual experiences.

What is clearly challenging is that today, more than ever, there are many ongoing changes regarding spirituality in academia, some of which are marked by the new characteristics of our students but mostly by the relationship between spirituality and psychology. This leads us down a road of many as yet unanswered, pertinent and thought-provoking questions. One issue will always stand out: normativity. Spirituality will always be value-laden

\footnotetext{
${ }^{47}$ A. JASTRZĘBSKI, "Gordon W. Allport's concept of the human person. On a possible dialog between philosophy and psychology," The Pluralist (2011), 1: 71-86.

48 A. JASTRZĘBSKI, "On the possibility of the psychology of spirituality," Counseling and Spirituality (2017), 36/1-2: 33-49.
} 
and hence will shape human judgments and actions. Taking into account the existing tension between psychology and religion, it won't be easy to decide where one should search for ultimate foundations of this normativity expressed in ethical obligations - in religion or in psychology?

\section{BIBLIOGRAPHY}

Chmielewski, M. “Duchowość.” In Leksykon duchowości katolickiej. Ed. M. Chmielewski, 226232. Lublin-Kraków: Wydawnictwo M, 2002.

DAniluk, M. "Duchowość chrześcijańska.” In Encyklopedia Katolicka, vol. 4. Ed. R. Łukaszyk, L. Bieńkowski, F. Gryglewicz, 317-330. Lublin: TN KUL, 1985.

DAROWSKI, R. Filozofia człowieka. Zarys problematyki. Kraków: WAM, 2002.

ELKINS, D.N. Beyond religion: A personal program for building a spiritual life outside the walls of traditional religion. Wheaton, IL: Quest Books, 1998.

Gall, T., Malette, J., Guirguis-Younger, M. "Spirituality and Religiousness: A Diversity of Definitions." Journal of Spirituality in Mental Health (2011), 13/3: 158-181. DOI/abs/10. 1080/19349637.2011.593404

Granat, W. Osoba ludzka. Próba definicji. Lublin: TN KUL, 2006.

HelminiaK, D.A. "Confounding the Divine and the Spiritual: Challenges to a Psychology of Spirituality." Pastoral Psychology (2008), 57: 161-182.

JASTRZĘBSKI, A. "Gordon W. Allport's concept of the human person. On a possible dialog between philosophy and psychology." The Pluralist (2011), 1: 71-86.

JASTRZĘBSKI, A. "On the possibility of the psychology of spirituality." Counseling and Spirituality (2017), 36/1-2: 33-49.

Koenig, H.G. Medicine, Religion and Health: Where Science and Spirituality Meet. West Conshohocken: Templeton Press, 2008.

OMAn, D. "Defining religion and spirituality." In Handbook of the psychology of religion and spirituality. Ed. R.F. Paloutzian, C.L. Park, 23-47. New York: The Guilford Press, 2013.

Puchalski, C., Ferrell, B., Virani, R., Otis-Green, S., Baird, P., Bull, J., Chochinov, H., Handzo, G., Nelson-Becker, H., Prince-Paul, M., Pugliese, K., Sulmasy, D. "Improving the quality of spiritual care as a dimension of palliative care: the report of the Consensus Conference." Journal of Palliative Medicine (2009), 12(10): 885-904.

RuBIN, J.B. "Psychoanalysis and spirituality." In Psychoanalysis and religion in the 21 st century: Competitors or collaborators. Ed. D.M. Black, 132-153. New York: Routledge, 2006.

SCHNEIDERS, S.M. "Spirituality in the Academy.” Theological Studies (1989), 50: 676-697.

ŠPidlik, T., GARgano, I., Grossi, V. "Duchowość Ojców Kościoła.” In Historia duchowości, vol. 3. Kraków: Homo Dei, 2004.

TAYLOR, Ch. Sources of the Self. The Making of the Modern Identity. Cambridge, MA: Harvard UP, 1989.

TISCHNER, J. Spór o istnienie czlowieka. Kraków: Znak, 1998.

Von Balthasar, H.U. "The Gospel as Norm and Test of All Spirituality in the Church." Concilium (1965), 9: 5-13. 
Wiseman, J.O. Spirituality and Mysticism: A Global View. Theology in Global Perspective Series. Orbis Books: Maryknoll, NY, 2006.

WiteK, S. "Duchowość religijna." Encyklopedia Katolicka, vol. 4. Ed. R. Łukaszyk, L. Bieńkowski, F. Gryglewicz, 330-334. Lublin: TN KUL, 1985.

WojCIESZEK, K.A. Na początku byta rozpacz... Antropologiczne podstawy profilaktyki. Kraków: Rubikon, 2005.

www.kul.pl/department-of-theology-of-catholic-spirituality,2733.html.

www.kul.pl/research,21678.html.

www.kul.pl/studies,21677.

www.teresianum.net/counseling-spirituale/presentazione.

www.teresianum.net/facolta.

www.teresianum.net/specializzazione-in-teologia-spirituale/ciclo-per-la-licenza-ts.

www.unigre.it/struttura_didattica/Spiritualita/index_en.php.

www.unigre.it/zz2_applicazioni/framework_en.php?adg_utente=unknown\&adg_pgm=204\&adg_ ua $=7$.

www.ustpaul.ca/program-new/contemplative-theology-and-spiritual-mentorship-314.htm.

www.ustpaul.ca/program-new/counselling-and-spirituality-302.htm.

www.ustpaul.ca/program-new/honours-bachelor-of-arts-in-human-relations-and-spirituality-324.htm.

Zaborowski, Z. Człowiek jego świat i życie. Próba integracji. Warszawa: Wydawnictwo Akademickie „Żak”, 2002.

\section{KONCEPCJE DUCHOWOŚCI NA UNIWERSYTETACH DZISIAJ}

\section{STRESZCZENIE}

W naszych czasach koncepcja, pojęcie lub rozumienie duchowości weszło w niezwykle dynamiczną fazę. Proces ten można również zaobserwować w sposobie nauczania duchowości na różnych uniwersytetach. Ogólnie mówiąc, w podejściu do studiowania duchowości można wyodrębnić cztery czynniki lub wymiary: ontologiczne albo fenomenologiczne oraz fundamentalne albo pragmatyczne. Celem tego artykułu jest zilustrowanie rozróżnienia naszkicowanego podziału w oparciu o wybrane przykłady programów uniwersyteckich, analiza porównawcza rozumienia duchowości i jej konsekwencji dla programów akademickich.

Jeden z możliwych przyszłych kierunków rozwoju duchowości można przedstawić jako proces stopniowego poszerzania jej rozumienia. Duchowość katolicka stanie się bardziej ekumeniczna (chrześcijańska), a następnie międzyreligijna - obecnie jesteśmy świadkami znaczącego zainteresowania buddyzmem, w końcu nawet niereligijna, tj. obejmująca wszystkie możliwe duchowe doświadczenia człowieka.

Słowa kluczowe: duchowość; teologia; uniwersytet. 